\title{
The Influence of Humor Styles on the Level of Academic Self-C Concept (ASC)
}

Horia Mihai Raboca, Daniela Cotoranu 


\title{
The Influence of Humor Styles on the Level of Academic Self-C Concept (ASC)
}

\author{
Horia Mihai Raboca ${ }^{a}$, Daniela Cotoranu ${ }^{\text {* }}$ \\ ${ }^{a}$ Faculty of Political, Administrative and Communication Sciences, Babeș-Bolyai University 1, Mihail Kogălniceanu Street, Cluj-Napoca, 400000, \\ Romania \\ ${ }^{b}$ Doctoral School of Administration and Public Policy, Faculty of Political, Administrative and Communication Sciences, Babeș-Bolyai University, \\ 1 Mihail Kogalniceanu Street, Cluj-Napoca, 400000, Romania \\ *Corresponding author: daniela.cotoranu@yahoo.com
}

\section{Abstract}

Keywords:

academic self concept, teachers' humor, students, humor style.
The use of humor by teachers can have a positive effect on improving the level of academic self concept and implicitly on motivation and academic results.

The present research aimed to investigate to what extent the humor styles practiced by teachers influence the level of academic self-concept (ASC) of students.

A number of 117 students who were enrolled in the master's programs in the field of public administration within the Faculty of Political, Administrative and Communication Sciences (FSPAC), Babeș-Bolyai University of Cluj-Napoca answered a questionnaire.

Our research shows that there is a link between the humor styles practiced by teachers and the level of ASC of students. Also, the findings indicate that the use of humor in the educational process can play a greate role, namely it can increase or decrease the level of ASC among students. In this sense, although the influence of students' humor styles on the ASC level of students is relatively weak, the connection is still significant.

\section{Zusammenfasung}

\section{Schlüsselworte:}

akademisches Selbstkonzept, Humor der Lehrer, Schüler, Humorstil.
Der Einsatz von Humor durch Lehrer kann eine effektive Praxis zur Verbesserung des akademischen Selbstverständnisses und implizit der Motivation und der akademischen Ergebnisse sein.

Die vorliegende Untersuchung zielte darauf ab, zu untersuchen, inwieweit die von Lehrern praktizierten Humorstile das Niveau des akademischen Selbstkonzepts (ASC) der Schüler beeinflussen.

Als solches wurde ein Fragebogen verwendet, an dem 117 Studierende teilgenommen haben, die in den Masterstudiengängen im Bereich der öffentlichen Verwaltung der Fakultät für Politik-, Verwaltungs- und Kommunikationswissenschaften (FSPAC) der Babeș-Bolyai-Universität Cluj eingeschrieben sind.

Unsere Forschung zeigt, dass Unsere Forschung zeigt, dass es einen Zusammenhang zwischen den von Lehrern praktizierten Humorstilen und dem ASC-Niveau der Schüler gibt. Die Forschungsergebnisse zeigen auch, dass der Einsatz von Humor im Bildungsprozess eine große Rolle spielen kann, nämlich: Er kann das Niveau der ASC-Mong-Schüler erhöhen oder senken. Obwohl der Einfluss des Humorstils der Schüler auf das ASCNiveau der Schüler relativ schwach ist, ist der Zusammenhang in diesem Sinne immer noch signifikant.

\section{Introduction}

Humor is one of the main mechanisms by which a conducive learning environment can be ensured, and depending on the style of humor practiced by the teacher, it can increase motivation and academic performance. Still, the use of an aggressive style of humor can make the student avoid participating in the course due to lack of self-confidence, but also the tense atmosphere during classes.

According to Korobkin (1988), humor can reduce anxiety and the threatening nature of the course by changing the tone of the training process. Also, some researchers believe that humor can be used in teaching sensitive areas, such as Sex Education (Adams, 1974), as well as in teaching high-difficulty courses such as Statistics, Research Design, and Tests and Measurements (Berk and Popham, 1995).

The way of teaching in Romania, whether it is a high school or a higher level, is quite a rigid process, lacking in humor, an aspect that can be seen as a consequence of the low academic performance and motivation.

Literature and specialized studies indicate that students not only learn and understand much better from teachers who have a high level of humor (Buskist et al., 2002), but there is also the establishment of a 
student-teacher relationship, but they also enjoy the learning process from them (Buskist et al., 2002). Thus, the use of humor can be an effective catalyst for teachers to encourage academic self-concept (ASC).

The aim of the research is to identify the extent to which teachers' humor styles influence the level of academic self-concept (ASC) of students. In other words, we tried to find out if the different styles of humor practiced by teachers in the educational process have a connection, respectively a positive or negative effect on the academic self concept (ASC) level of students.

We believe that depending on the style of humor used the concept of academic self can be positively or negatively influenced. Thus, we will briefly analyze the four styles of humor found in the literature.

\section{Theoretical foundation}

\subsection{The humor styles}

According to literature, humor is defined as any communicative instance perceived as humorous (Martineau, 1972), as a form of communication that produces a positive cognitive and affective response from listeners (Crawford, 1994, p.57), but also as a coping strategy, a defense mechanism or an interpersonal communication behavior.

The humor style indicates "the way in which behavior and stylistic features are achieved" (Martin, p.48, 2003) functions, forms or ways in which the individual uses humor (Martin, 2003, p. 51). Literature indicates four styles of humor amongst which two (affiliative humor and self-Enhancing humor) may have positive effects on ASC and the other two (aggressive humor and self-defeating humor) may have negative benefits on ASC:

\section{- Affiliative humor}

Practicing this style of humor aims to create a sense of cohesion, of fellowship, happiness and wellbeing. This style of humor is often used as a way to relax a critical situation, to amuse others by using jokes and involves the benign use of humor. In addiction, affiliative humor is found in individuals who tend to amuse others by telling jokes and funny stories and engaging in spontaneous play, in order to facilitate relationships and reduce interpersonal tensions (Lefcourt, 2001).

Thus, according to Kuiper, Grimshaw, Leite, and Kirsh (2004) affiliative humor styles were associated with higher self-esteem, better ability to understand the subject, higher performance and satisfaction.

Therefore, we can say that affiliate humor can have positive benefits on the concept of academic self, in the sense that the adoption of an affiliate humor by a teacher is positively correlated with a high level of ASC, positive emotions and academic results and is negatively correlated with the level of anxiety and depression in among students.

\section{- Self-Enhancing humor}

This style of humor is characterized by the use of jokes and humorous treatment of difficult situations being an effective way to cope with stress and at the same time it is a defense mechanism against other negative feelings.

Due to its characteristics it is believed that this type of humor refers to the fact that humor is used as a coping mechanism and is most consistent with the Freudian definition of humor as a healthy defense mechanism (Martin, Kuiper \& Olinger, 1993).

At the same time it is characterized by the use of a coping strategy to regulate negative emotions and involves a humorous view of the realities of life (Kuiper et al., 2010). On the other hand, this style of humor is most often encountered in people who have the ability to laugh at themselves, the problem they face, precisely in the idea of putting in a positive light or difficult situation and to treat any problem positively. This style of humor contributes significantly to reducing stress, optimism, improving self-esteem, and people who resort to this style of humor are less prone to neuroticism.

\section{- Aggressive humor}

In terms of aggressive humor, Kuiper et al. (2004) showed that aggressive humor is negatively correlated with depression, and anxiety, low academic results and low self-esteem.

Aggressive humor is one of those styles of humor that has a negative impact on others, and is characterized by the use of sarcasm, ridicule, and teasing of others and is used to criticize and manipulate others (Kuiper, 2004).

In addition, aggressive humor is characterized by racism, sexism and is positively associated with high levels of neuroticism and lower levels of pleasure and conscientiousness. According to the literature, people who use this style of humor tend to have a higher level 
of hostility and aggression and are more common among men.

Following the review of the literature, we can say that those who use aggressive humor are perceived as lacking concern and respect for others because they use course and vulgar language as well as sarcastic and mean spirited techniques when making fun of others (Kuiper et al., 2010). This aspect can be explained by the fact that aggressive humor is seen as having the role of division being the result of a constraint.

Thus, given the characteristics of aggressive humor, it has a negative effect on the level of academic self-concept.

\section{- Self-defeating humor}

This last style of humor is used by those people who tend to amuse others at their expense, make people laugh at their own weaknesses and even ridicule themselves, in order to get approval from other people (Martin, 2003). Although individuals with this style are seen as entertaining, there is an element of emotional neediness and low self-esteem in them that justifies the use of humor as a way of hiding negative feelings (Fabrizi \& Pollio,1987).

Additionally, from a psychological point of view, this style of humor can be an unhealthy form of humor, and is sometimes used by the bullies' targets to try to avoid attacks and is positively associated with high levels of anxiety, depression, and psychiatric symptoms, but negatively associated with self-esteem, motivation, and psychological well-being. (Erickson \& Feldstein, 2007).

Therefore, because the self-defeating humor is characterized by excessive use of contempt and cynicism and involves amusing others by satirizing oneself it can have negative effects on the academic self concept (ASC).

In conclusion, the effective use of humor by teachers can lead to increased levels of academic self concept among students depending on the style of humor adopted.

Moreover, the use of humor by teachers is even more beneficial in the current pandemic situation, given the development of online courses. According to studies, the online academic system is less efficient than the classic teaching system, it is characterized by lack of motivation, monotony, difficulty concentrating, digital difficulties (Raboca \&Cotoranu,
2020), so using the humor during teaching hours can help improve to academic self concept.

Literature indicates four styles of humor amongst which two styles of humor (affiliative humor and selfenhancing humor) can have positive effects / benefits on ASC, being positively associated with a high level of academic performance, self-esteem, motivation. The other two styles of humor (self-defeating humor and aggressive humor) can have negative effects / benefits on ASC being negatively associated with lower self-esteem, greater depression and anxiety, and negative judgments of self-competence.

\subsection{Academic Self-Concept (ASC)}

Academic Self-Concept (ASC), in general, can be defined as the way in which individuals perceive their own academic abilities, respectively describes a student's perception of his own ability to interpret academic efforts and have academic results (Bong \& Skaalvik, 2003; Trautwein et al., 2006). According to other studies, ASC is made up of a set of attitudes, beliefs, and perceptions that students have and which are related to their academic abilities and academic performance (Lent, Brown \& Gore, 1997). Last but not least, Cokley (2000)) considers that ASC also includes a comparative assessment dimension in the sense that students assess their own academic attitudes and skills compared to other students.

From certain points of view, the interest for this concept is given by the fact that ASC can be considered a significant predictor of students' academic achievement. In fact, ASC can explain many aspects related to school functions, including not only aspects such as: student motivation, results of school and academic performance, persistence of tasks and self-regulation learning as well as those related to basic and transversal school skills such as be: reading, writing, communicating and solving problems. In this regard, a number of studies suggest that there is a significant correlation between ASC and student GPA and implicitly with academic achievement (Gerardi, 1990; Areepattamannil \& Freeman, 2008; Ghazvini, 2011; Wu et al., 2021). Also, Dixson (2019) claims that the determination and involvement of students explained much less of the variation of GPA compared to ASC.

Regarding the factors that influence ASC, Cokley (2000) considers that both GPA and the quality of student-faculty interactions or class status are very good predictors of ASC. It should also be remembered 
that Ferla et al. (2009) showed that ASC strongly influences students' academic self-efficacy beliefs, respectively ASC is a good predictor (and mediator) for affective-motivational variables.

In general, for measuring ASC, the instrument developed by Reynolds entitled "Academic SelfConcept Scale" (ASCS) is used as a measuring instrument - which was especially developed to assess the academic self-concept of college students. The interest in using this tool is that it has a high level of validity and reliability, confirmed by a large number of psychometric studies (Cokley, et al., 2003; Reynolds, 1988; Reynolds, 1980; Williams and Chung, 2013; Minchekar, 2019).

\section{Research methodology}

From a methodological point of view, the research is based on an opinion poll addressed to a number of 117 students enrolled in a master's programs in public administration at the Faculty of Political, Administrative and Communication Sciences (FSPAC), Babeș-Bolyai University of Cluj-Napoca.

Most of the respondents are in the second year of their master's program (table1). The research instrument used was the questionnaire. Respondents' answers were anonymous.

Table 1. Characteristics of the sampled population

\begin{tabular}{|c|c|}
\hline Year of study & Nr. of students interviewed (\%) \\
\hline First year & $46(39,3)$ \\
\hline Second year & $71(60,7)$ \\
\hline Total & $117(100)$ \\
\hline
\end{tabular}

Also from a methodological point of view, the questionnaire used two large sections: the first section aimed to identify the humorous styles of teachers from the students' perspective. The evaluation of humor styles was done using the instrument called "Humor Styles Questionnaire" (HSQ) (Martin et al., 2003). HSQ consists of 32 articles divided into four dimensions, correlated with each other and referring to two styles of adaptive humor, positive and beneficial (affiliate and self-improvement) and other two negative and harmful styles (aggressive and selfdefeat).

The scale used in the evaluation is a seven level Likert scale ( $1=$ strongly against, $7=$ totally agree $)$. High scores for each dimension indicate high levels for that style of humor.

Section two aims to identify the level of ASC among students. Thus, to identify the level of ASC we used, as a measuring instrument, a modified variant of
ASCS, namely (1) a short form of the original form of ASCS (ASCS-SF; Sweet, 2018); (2) the ASCS-SF measurement scale used is at seven levels ( $1=$ strongly against, $7=$ total agreement.) A high score identified indicates a high level of ASC, while a low score shows a low ASC level.

\section{Results and discussions}

In order to identify the link between teachers 'humor styles and students' ASC level, we used a statistical correlation analysis. Although the result of the correlation analysis (Table 2) shows that we can talk about a link between the humor styles practiced by teachers and the level of ASC of students, things are quite complicated.

On the one hand, not all humor styles have an impact on students' ASC levels. On the other hand, the effect of the impact is different in the sense that certain styles of humor have a negative impact on the ASC level of students, while other styles of humor have a positive effect.

In this sense, it is obvious that the practice of negative humor styles by teachers (Aggressive and Self-defeating humor style), although they don't have a great impact, contributes to the decrease of the ASC level of students. At the same time, the use of the affiliative humor style contributes to the increase of the ASC level of the students, although the influence is relatively small.

Table 2. Correlation analysis between different humor styles and ASC level of students

\begin{tabular}{|c|c|c|}
\hline & & $\begin{array}{l}\text { Academic Self- } \\
\text { Concept (ASC) }\end{array}$ \\
\hline $\begin{array}{c}\text { Academic } \\
\text { Self-Concept } \\
\quad(\text { ASC })\end{array}$ & $\begin{array}{c}\text { Pearson Correlation } \\
\text { Sig. (2-tailed) } \\
\text { N }\end{array}$ & $\begin{array}{c}1 \\
117\end{array}$ \\
\hline $\begin{array}{l}\text { Affiliative } \\
\text { humor }\end{array}$ & $\begin{array}{c}\text { Pearson Correlation } \\
\text { Sig. (2-tailed) } \\
\mathrm{N}\end{array}$ & $\begin{array}{c}.365^{* *} \\
.000 \\
117\end{array}$ \\
\hline $\begin{array}{c}\text { Self- } \\
\text { enhancing } \\
\text { humor }\end{array}$ & $\begin{array}{c}\text { Pearson Correlation } \\
\text { Sig. (2-tailed) } \\
\text { N }\end{array}$ & $\begin{array}{c}-.056 \\
.551 \\
117\end{array}$ \\
\hline $\begin{array}{l}\text { Aggressive } \\
\text { humor }\end{array}$ & $\begin{array}{c}\text { Pearson Correlation } \\
\text { Sig. (2-tailed) } \\
\mathrm{N}\end{array}$ & $\begin{array}{c}-.247^{* *} \\
.007 \\
117\end{array}$ \\
\hline $\begin{array}{l}\text { Self-defeating } \\
\text { humor }\end{array}$ & $\begin{array}{c}\text { Pearson Correlation } \\
\text { Sig. (2-tailed) } \\
\mathrm{N}\end{array}$ & $\begin{array}{c}-.182^{*} \\
.049 \\
117\end{array}$ \\
\hline
\end{tabular}




\section{Discussions}

Therefore, according to the literature there is a significant link between humor and academic self concept. Thus, there is a positive link between academic self concept and humor, a greater temporal stability of ASC and increased positive self-content (sociability) anddecreasednegative self-content (depressive personality) (Kuiper and Martin, 2009).

Also, a high level of humor among teachers can be positively associated with a high level of self-esteem, academic performance and lower levels of perceived stress.

From a certain point of view, research findings show that humor is used in the educational process can play a big role, namely: it can increase or decrease the level of ASC among students. In this respect, although the influence of students' humor styles on the ASC level of students is relatively small, the connection is still significant.

Therefore, we believe that it is important to pay attention and be aware of the type of humor used in the educational process. Basically, it is not the same for teachers in the educational process to use one style or another of humor.

If negative educational styles are used in the educational process, humorous types such as: Aggressive and Self-defeating, we must be aware that these are styles, among other things, by the fact that they can reduce the ASC level of students reduces and the level of achievements school and academic performance of students. In other words, we should not be surprised that among students, sooner or later there will be a lack of academic performance due to the use of negative humor styles.

At the same time, if we want to boost or increase the level of ASC and implicitly the level of academic performance of students, one of the honorable methods that can be used by teachers is to use, among other things, an affiliate style of humor.

\section{Authors note:}

The authors have equal contributions to this article.

Horia Mihai Raboca is a senior lecturer at the Faculty of Political, Administrative and Communication Sciences (Babeș-Bolyai University, Cluj-Napoca), Department of Public Administration and Management. He graduated with a bachelor's degree in economics and a master's degree in public administration, obtaining the $\mathrm{PhD}$ in management. Research field of interest: evaluating the performance of public organizations and systems, measuring customer satisfaction of public institutions, education systems and public school. Examples of published articles: "Determinants of customer satisfaction and service quality - the case of Romanian public services" and "ICT in education-exploratory analysis of students. Perceptions regarding ICT impact in the educational process".

Daniela Cotoranu is a $\mathrm{PhD}$ student at the Doctoral School of Administration and Public Policy, Faculty of Political, Administrative and Communication Sciences (Babeș-Bolyai University, Cluj-Napoca). She graduated with a bachelor's degree in public administration and a master's degree in human resources management in the public sector. Research field of interest: measuring the level of resilience in the public sector, life quality, evaluation of programs and projects, evaluation of the efficiency and performance of education systems. Examples of published articles: "The Resilience of Civil Servants from the Romanian Rural Environment", "The Efficiency of the Online Academic Teaching Process During the Pandemic Covid-19" and "The psychological impact of the Covid-19 pandemic on students at Babeș-Bolyai University".

\section{References}

Areepattamannil, S. \& Freeman, J. G. (2008). Academic achievement, academic self-concept, and academic motivation of immigrant adolescents in the greater Toronto area secondary schools. Journal of Advanced Academics, 19, 700-743.

Berk, R. A. \& Popham, W. J. S. (1995). Jocular approaches to teaching measurement, statistics and research design. Minicourse presented at the annual meeting of the American Educational Research Association, April, San Francisco, CA.

Buskist, W., Sikorski, J., Buckley, T. \& Saville, B.K. (2002). Elements of master teaching. In S.F. Davis \& W. Buskist (Eds.), The teaching of psychology: Essays in honor of Wilbert J. McKeachie and Charles L. Brewer (27-39). Routledge.

Bong, M. \& Skaalvik, E.M. (2003). Academic SelfConcept and Self-Efficacy: How Different Are They Really?. Educational Psychology Review, 15, 1-40.

Cokley, K. (2002). An Investigation of Academic SelfConcept and Its Relationship to Academic Achievement 
in African American College Students. Journal of Black Psychology, 26 (2), 148-164.

Cokley, K., Komarraju, M., King, A., Cunningham, D. \& Muhammad, G. (2003). Ethnic differences in the measurement of academic self-concept in a sample of African American and European American college students. Educational and Psychological Measurement, 63(4), 707-722.

Erickson, S. J., \& Feldstein, S. W. (2007). Adolescent humor and its relationship to coping, defense strategies, psychological distress, and well-being. Child Psychiatry and Human Development, 37(3), 255-271.

Dixson, D. D. (2021). Is grit worth the investment? How grit compares to other psychosocial factors in predicting achievement. Current Psychology, 40, 3166-3173.

Fabrizi M. S., Pollio, H. R. (1987). Are funny teenagers creative? Psychological Reports. 61, 751-761.

Ferla, J., Valcke, M. \& Cai, Y. (2009). Academic selfefficacy and academic self-concept: Reconsidering structural relationships. Learning and Individual Differences, 19(4), 499-505.

Ghazvini, S. D. (2011). Relationships between academic self-concept and academic performance in high school students. Procedia - Social and Behavioral Sciences, 15, 1034-1039.

Huimin $\mathrm{Wu}$, Yiqun Guo, Yingkai Yang, Le Zhao \& Cheng Guo. (2021). A Meta-analysis of the Longitudinal Relationship Between Academic Self-Concept and Academic Achievement. Educational Psychology Review. https://doi.org/10.1007/s10648-021-09600-1

Korobkin, D. (1988). Humor in the classroom: Considerations and strategies. College Teaching. 36, 154-158.

Kuiper N.A., Kirsch G.A, Leite C. (2010). Reactions to humours comments and implicit theories of humor styles. Europen's Journal of Psychology, 6 (3), 236-266.

Kuiper, N.A., Grimshaw, M., Leite, C., Kirsh, G. (2004). Humor is not always the best medicine: Specific components of sense of humor and psychological wellbeing. Humor: International Journal of Humor Research, 17(1), 135-168.

Kuiper, N.A., Martin, R. A. (2009). Humor and selfconcept. Humor. 3(6), 251-270 https://doi.org/10.1515/humr.1993.6.3.251

Lent, R. W., Brown, S. D. \& Gore, P. A., Jr. (1997). Discriminant and predictive validity of academic self- concept, academic self-efficacy, and mathematicsspecific self-efficacy. Journal of Counseling Psychology, 44(3), 307-315.

Lefcourt, H. (2001). Humor: The Psychology of Living Buoyantly. New York: Academic/Plenum Publishers.

Martin, R. A., Kupier, N. A., Olinger, L. J., Dance, K. A. (1993). Humor, coping with stress, self-concept, and psychological well-being. Humor, 6(4), 89-104.

Minchekar, Vicas S. (2019). Academic Self Concept Scale for Adolescents: Development, Reliability and Validity of ASCS. International Journal of Research and Analytical Reviews, 6 (1), 26-30.

Martin, R. A., Puhlik-Doris P., Larsen,G., Gray, J. \& Weir, K. (2003). Individual differences in uses of humor and their relation to psychological well-being: development of the humor styles questionnaire. Journal of Research in Personality, 37, 48-75.

Reynolds. W. (1980). Initial Development and Validation of the Academic Self-Concept Scale. Educational and Psychological Measurement. 40, 1013-1016.

Reynolds. W. (1988). Measurement of Academic SelfConcept in College Students. Journal of Personality Assessment. 52 (2), 223-240.

Raboca M., Cotoranu D. (2020). The Efficiency of the Online Academic Teaching Process During the Pandemic Covid-19. Educatia 21 Journal, (19), 119-126. https://doi.org/10.24193/ed21.2020.19.15

Sweet, Jonathan A. (2018). Predicting Undergraduate Student Course Success in a Lecture Capture Quantitative Methods Course. Florida Atlantic University. ProQuest Dissertations Publishing, ProQuest document ID: 2054017476. https://www.proquest.com/dissertationstheses/predicting-undergraduate-student-coursesuccess $/$ docview $/ 2054017476 /$ se-2 ?accountid $=8013$

Trautwein, U., Lüdtke, O., Köller, O. \& Baumert, J. (2006). Self-Esteem, Academic Self-Concept, and Achievement: How the Learning Environment Moderates the Dynamics of Self-Concept. Journal of Personality and Social Psychology 90 (2), 334-49.

Williams, W. \& Chung, B. (2013). Do cultural attitudes matter? The role of cultural orientation on academic selfconcept among Black/African college students. Journal of College Counseling, 16, 228-242. 